\title{
Sinking Mafic Body in a Reactivated Lower Crust: A Mechanism for Stress Concentration at the New Madrid Seismic Zone
}

\author{
by Fred F. Pollitz, Louise Kellogg, and Roland Bürgmann
}

\begin{abstract}
We propose a geodynamic model for stress concentration in the New Madrid seismic zone (NMSZ). The model postulates that a high-density (mafic) body situated in the deep crust directly beneath the most seismically active part of the NMSZ began sinking several thousands of years ago when the lower crust was suddenly weakened. Based on the fact that deformation rates in the NMSZ have accelerated over the past 9 k.y., we envision the source of this perturbation to be related to the last North American deglaciation. Excess mass of the mafic body exerts a downward pull on the elastic upper crust, leading to a cycle of primary thrust faulting with secondary strike-slip faulting, after which continued sinking of the mafic body reloads the upper crust and renews the process. This model is consistent with the youth of activity, the generation of a sequence of earthquakes, and the velocity evolution during interseismic periods, which depend upon the density contrast of the mafic body with respect to the surrounding crust, its volume, and the viscosity of the lower crust.
\end{abstract}

\section{Introduction}

The New Madrid seismic zone (NMSZ) is the site of large intraplate earthquakes, last rupturing in 1811-1812 in a sequence of $M_{w} 7.2-7.5$ (Hough et al., 2000) or possibly $M_{w} \sim 8$ (Johnston, 1996) earthquakes, but having ruptured previously about once every 400-600 yr over at least the past 2000 yr (Wesnousky and Leffler, 1992; Tuttle and Schweig, 1995; Kelson et al., 1996). This active seismic zone occupies the center of a failed rift (Reelfoot Rift), which involved rifting and emplacement of mafic plutons throughout the crustal column in the Late Proterozoic-Late Cambrian and either reactivation (Ervin and McGinnis, 1975; Thomas, 1991) or thermal perturbation (Cox and Van Arsdale, 1997) in the Late Cretaceous. Focal mechanism studies (e.g., Herrmann and Canas, 1978; Herrmann, 1979) and microseismicity studies (e.g., O'Connell et al., 1982; Stauder, 1982; Chiu et al., 1992) reveal that the NMSZ is characterized by two SW-NE-trending zones of strike-slip faulting on vertical planes, with a zone of thrust faulting on $\sim 30^{\circ} \mathrm{SW}$-dipping planes within the left step-over between the strike-slip fault zones. Most seismicity is concentrated between 4- and 14-km depth.

Since microseismic activity clearly defines two distinct linear trends accommodating strike-slip faulting on nearly vertical faults, previous efforts to explain the occurrence of these earthquakes have focused on stress concentration mechanisms designed to generate right-lateral shear stress on vertical planes coinciding with these arms. Here we briefly summarize these models. One model (Liu, 1993; Liu and Zoback, 1997) postulates stress amplification in an upper crustal stress guide due to thermal weakening of lower crust and upper mantle, and it is consistent with slightly elevated heat flow (Swanberg et al., 1982) and low uppermost mantle seismic velocities (Mitchell et al., 1977; AlShukri and Mitchell, 1987) in the NMSZ. In another model (Gomberg and Ellis, 1994) the seismic zone is loaded with slip on deep vertical faults, which is particularly effective in loading the strike-slip fault segments of the NMSZ. The models of McKeown and Diehl (1994) and Braile et al. (1986) are based, respectively, on the presence of high pore fluid pressure and weakness of pre-existing faults in the Reelfoot Rift, and they are consistent with the fact that reactivation of ancient rifts under a new stress field is established in many other regions. The models of Campbell (1978), Long (1978), and Hildenbrand (1985) are based on the contrast in elastic moduli between the NMSZ and the Missouri batholith, which intersects the NMSZ along its most seismically active parts. Under this condition, the background horizontal stress field will concentrate shear stress in the weak (intersection) zone. The model of Stuart et al. (1997) is based on seismic and gravity data that indicates that, in addition to widespread exposed or shallowly buried basalts, the NMSZ is underlain by a lense-shaped, high-density rift pillow (Ginzburg et al., 1983; Mooney et al., 1983) of dimension of about $10^{4} \mathrm{~km}^{3}$ within the lower crust (likely mantle melt intrusions in the deep crust) and centered on the locus of current seismic activity (Fig. 1). In their model, right-lateral strike-slip faulting 


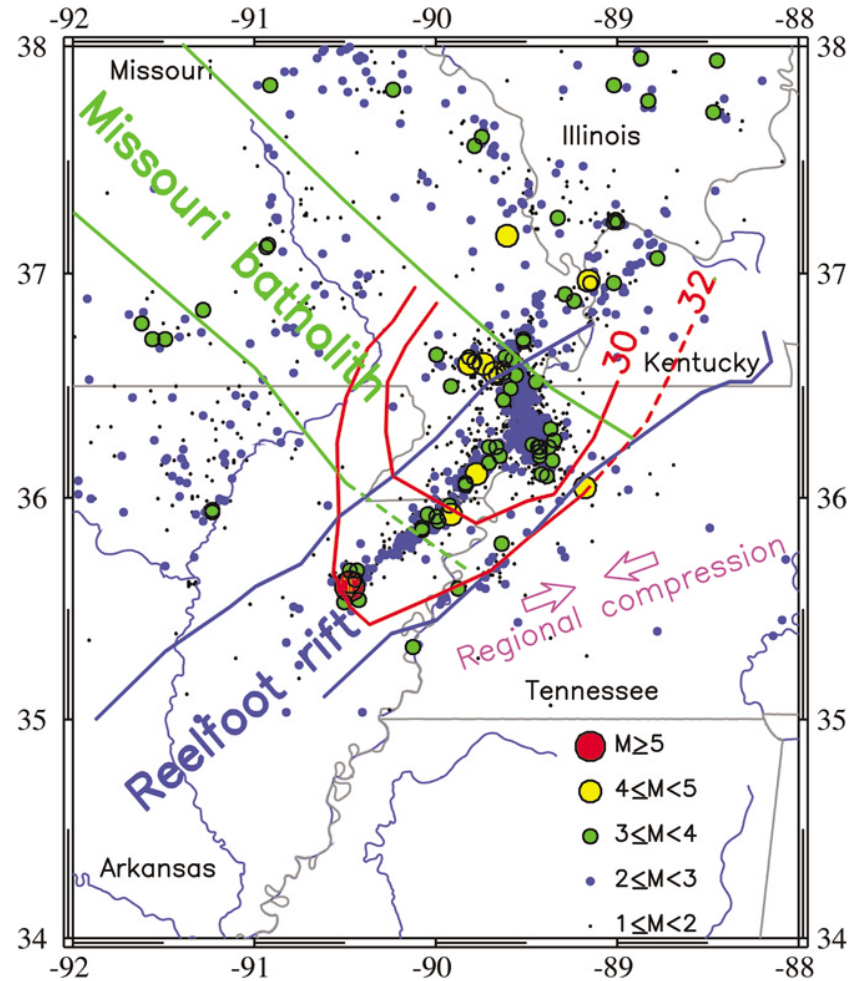

Figure 1. Seismicity of the NSMZ and related structural features. A rift pillow imaged by seismic refraction and gravity data (Stuart et al., 1997) is outlined with red contours, with depth to the top of the rift pillow given in kilometers. A conservative estimate of its volume is $10 \times 30 \times 50 \mathrm{~km}^{3}$. With a density contrast with respect to the surrounding lower crust of $150 \mathrm{~kg} / \mathrm{m}^{3}$, assuming the rift pillow had been $50 \%$ supported by elastic strain in the lower crust prior to weakening, the downward pull exerted by the rift pillow is $1.1 \times 10^{16} \mathrm{~N}$. Compiled from figure 1 of Stuart et al. (1997) and a seismicity catalog provided by the Center for Earthquake Research and Information, University of Memphis.

above the rift pillow is generated by supposing that the lower crust above the rift pillow interface is weak and that it flows. Stress concentration on the vertical faults in the Reelfoot Rift is then accomplished by resolving background ENE-WNW horizontal compressive stress on the two-sided, dipping rift pillow-to-crust interface. A recent model (Kenner and Segall, 2000) postulates that an assumed sudden recent weakening of the lower crust thereby concentrated background tectonic stress onto the relatively thin upper crust. An attractive feature of this model is that it provides a possible explanation for the occurrence of repeating sequences of NMSZ earthquakes following a long period of inactivity.

Each of these models fails to explain one or more primary observations that we consider critical for explaining stress concentration:

1. There is a disproportionate amount of thrust faulting relative to strike-slip faulting associated with the NMSZ (fig- ure 15 of Hildenbrand and Hendricks, 1995), including the persistence of thrust faulting southeast of the stepover zone bridging the two major strike-slip zones (Herrmann, 1979; Fig. 1). Re-evaluation of the magnitude of the three largest events in the 1811-1812 sequence (Hough et al., 2000) suggests that the 7 February 1812 earthquake (i.e., that thought to be associated with thrust faulting on the Reelfoot fault) was the largest. They conclude (Hough et al., 2000, p. 23,860): “ . . rather than being a mostly strike-slip system with thrust faulting associated with a compressional step-over, thrust faulting may have been the dominant mechanism associated with the 1811-1812 New Madrid sequence."

2. Significant thrust faulting and, by implication, strike-slip faulting has occurred only during the Late Quaternary and Holocene based on the uplift rate and displacement of horizontal seismic reflectors beneath the Lake County uplift (e.g., Van Arsdale et al., 1998; Van Arsdale, 2000).

3. Earthquake occurrence in the NMSZ has been fairly regular since it initiated (Wesnousky and Leffler, 1992; Tuttle and Schweig, 1995; Kelson et al., 1996).

The second observation suggests that an essential ingredient in viable models is a mechanism for recent weakening of the lower crust. Similarly, only those models that postulate a weak lower crust or upper mantle beneath the NMSZ (e.g., Liu and Zoback, 1997; Stuart et al., 1997; Kenner and Segall, 2000) have the capability of reloading faults to produce a sequence of earthquakes. Finally, similar conditions (e.g., elevated heat flow and pre-existing faults) exist in many relatively quiet intraplate regions, and it is not clear, in the context of existing models, what makes the NMSZ unique in its exceptional seismic activity.

\section{Weakening Mechanism}

We propose that either a thermal or pressure perturbation related to the last North American deglaciation affected the region around the NMSZ during the Holocene (Fig. 2). Our model requires that this perturbation led to a sudden weakening of the lower crust, possibly in conjunction with upper mantle weakening. Several mechanisms of producing this sudden weakening are possible but practically unconstrained given the current knowledge of the physical state of the NMSZ. It appears likely, however, that any plausible weakening mechanism must involve heat transport to the lower crust and that this heat transport must be advective rather than conductive, since conductive heat transport would be far too slow to have produced a recent change.

Glacial unloading of the last North American glacial maximum took place over a $\sim 10$-k.y. time interval (Fig. 2), relatively fast compared with the timescale of relaxation of mantle materials (Hitchings et al., 1989; Karato and Wu, 1993; Peltier and Jiang, 1996) as well as the timescale of the original glacial loading. Thus, even though the final relaxed postglacial state (yet to be realized) should be close to the 
18,000 years ago

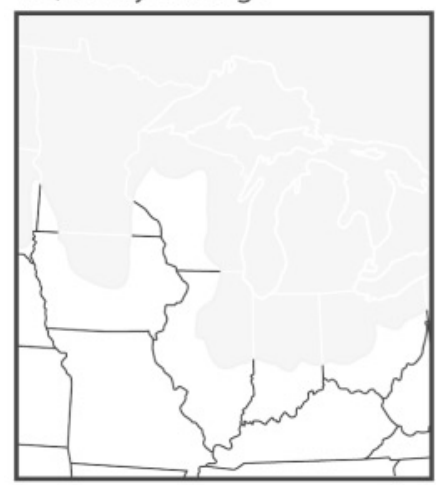

10,000 years ago

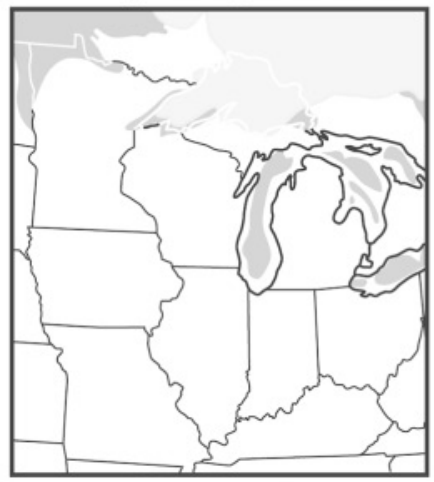

14,000 years ago

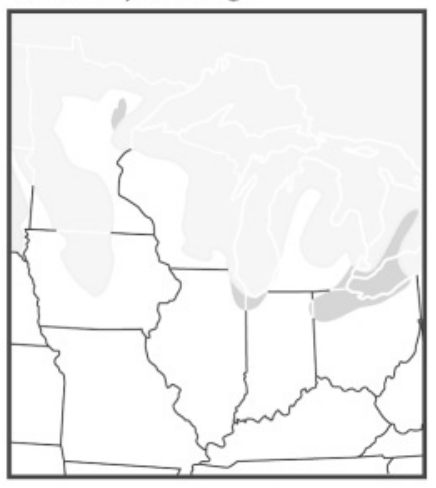

8,000 years ago

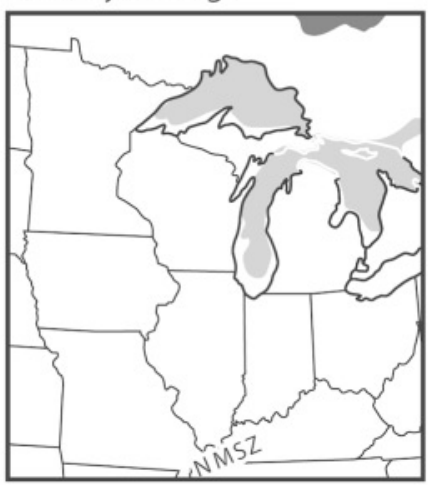

12,000 years ago
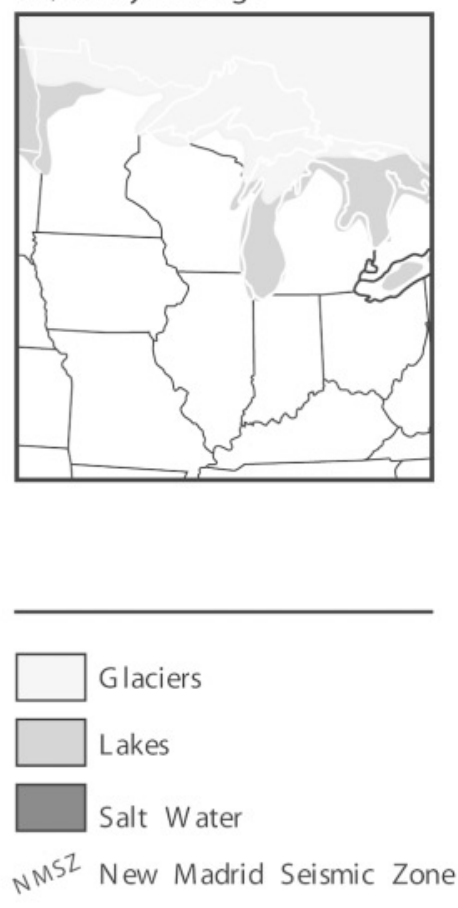

Figure 2. Glacial unloading of the last North American glacial maximum based on Dyke and Prest (1987) as depicted by http://www.museum.state.il.us/exhibits/larson/ glaciers.html.

preglacial state, the rapidity of relaxation compared with the buildup of the ice load would yield an evolving transient state that is unique to the postglacial epoch. During the relatively rapid early relaxation phase following unloading, viscoelastic calculations (e.g. Johnston et al., 1998) show that transient pressure perturbations of several megapascals may have been generated at shallow mantle depths at distances approximately $500 \mathrm{~km}$ outside the perimeter of the former ice sheet, the approximate situation of the NMSZ (Fig. 2). The mechanism relating a postglacial perturbation to a sharp Holocene acceleration in NMSZ deformation rates (Van Arsdale, 2000), however, is unclear. We regard the following two possibilities are the chief candidates, though other explanations are certainly possible (Kenner and Segall, 2000; Grollimund and Zoback, 2001):

1. Deglaciation produced pressure changes that induced pressure-release melting of hot patches of mantle material that had been slowly diffusing upward from the deeper mantle since passage of the Bermuda hotspot approximately 100 m.y. B.P. (Crough et al., 1980; Cox and Van Arsdale, 1997). This would have resulted in a rapid transfer of heat to the lower crust, causing it to weaken and initiate the young $\left(<\sim 10^{4} \mathrm{yr}\right)$ cycle of deformation in the New Madrid seismic zone. In their study of Icelandic melt production during interglacial periods, Jull and McKenzie (1996) showed that pressure-release melting may be induced by deglaciation of a thin lithosphere overlying a spreading center. Transient pressure perturbations of a few megapascals are sufficient to accelerate the melt production of mantle volumes that have risen above the solidus depth and already contain partial melt. The situation in the NMSZ is obviously different because of the lack of heat input since about 100 m.y. B.P., but this mechanism may be applicable if passage of a mantle plume at that time left behind patches of metasomatized mantle that remained susceptible to melting by a subsequent perturbation, as Baker et al. (1998) have proposed for the generation of fertile lithosphere upon passage of the Afar plume beneath Yemen. Such mantle has greatly reduced solidus temperature and is very sensitive to subsequent thermal and pressure perturbations (White and McKenzie, 1989). Another, but less likely, possibility is that the dynamic pressure associated with postglacial viscoelastic flow induced localized upward transport of mantle material of several kilometers. Although only about $1 \mathrm{~km}$ of vertical transport is predicted for postglacial flow on laterally homogeneous models, much greater localized vertical transport is conceivable if the viscosity structure is laterally variable. This, perhaps in combina- 
tion with the existence of mantle patches already close to the solidus temperature, could increase the potential for the pressure-release mechanism to be operable.

2. Shear heating in the lower crust and upper mantle generated by postglacial flow raised the temperature of these regions and weakened them. This effect is generally small on laterally homogeneous viscoelastic models, but localization of flow within thin channels in the lower crust or upper mantle, such as produced by heterogeneity in the mantle lithosphere (Schott et al., 1999), is a possibility.

\section{New Model of Stress Concentration}

Following Stuart et al. (1997), we postulate an active role for the relatively dense rift pillow in concentrating stress in the NMSZ. We propose that, after its emplacement, and subsequent to the most recent thermal perturbation in the early Late Cretaceous (Cox and Van Arsdale, 1997), the large body cooled and was partially supported by depression of the crust-mantle boundary (Stuart et al., 1997) but also partially supported by the lower crust. The rift pillow remained in this stable situation until an early Holocene perturbation weakened the lower crust (and possibly the upper mantle). Upon this weakening, dynamic support for the negatively buoyant mafic body was removed, and the body began sinking. Depending on the geometrical shape and continuity of the body with respect to the upper crust, this sinking induced a downward pull on the upper crust through either of two mechanisms:

1. The mafic body is mechanically connected with the upper crust, in which case the negative buoyancy of the body would be directly transferred from the lower crust to a relatively small area at the base of the upper crust.

2. The mafic body is isolated in the lower crust and is not directly coupled to the upper crust. In this case, sinking of the body induces strong fluid pressure gradients in the surrounding ductile lower crust, which couple into a downward force exerted on the upper crust.

Available data can neither confirm nor exclude either scenario, but the consequences of the two mechanisms are expected to produce qualitatively similar flow patterns in the lower crust and resultant time-dependent stress patterns in the upper crust. However, given the fact that the apex of the rift pillow reaches no higher than $\sim 25-\mathrm{km}$ depth (Stuart $e t$ al., 1997), we regard the second mechanism as the more likely and shall focus our attention on it. Calculations presented in the next section demonstrate that, in the presence of the regional ENE-WSW compressive stress, the downward load would strongly promote thrust faulting in the region directly above the rift pillow, which coincides with the step-over zone where historic thrust faulting is known to have occurred (Fig. 1).

This model is a variation on that presented by Grana and Richardson (1996), who invoked the gradual sinking of the dense rift pillow since the last known heating event (ca. 100 m.y. B.P.) within very high viscosity lower crust and mantle (viscosity $>\sim 10^{23}-10^{25} \mathrm{~Pa} \mathrm{sec}$ ). Their model is consistent with Cenozoic subsidence within the northern Mississippi embayment (Ervin and McGinnis, 1975), and they propose that it may explain stress rotations within the NMSZ relative to the background horizontal stress field. However, it implies essentially constant and extremely low deformation rates. The new model is capable of producing a sequence of earthquakes such as those which have occurred within the past few thousand years (Van Arsdale, 2000), and it is contingent only upon recent weakening of the lower crust.

\section{Consequences of Lower Crustal Weakening}

\section{Conceptual Model}

A complete representation of a seismic cycle in the NMSZ would consist of the effects of (1) application of a load, in this case arising from the constant downward force being exerted in the deep crust, (2) earthquakes that occur in the upper crust as stress levels exceed a certain limit appropriate for the pre-existing faults that populate the NMSZ, and (3) relaxation of the ductile lower crust driven by processes (1) and (2). Process (2) involves primarily thrust and strike-slip faulting earthquakes within well-defined fault zones (Fig. 1), but more generally it may be thought of as cataclastic flow of the upper crust in response to the stresses applied to it. The character of this flow is likely to be complicated in the deeper upper crust, where aseismic slip may play a major role. Given this and the uncertain slip associated even with the historical 1811-1812 events, it is difficult to estimate relaxation effects from process (2). For simplicity, we evaluate the stress evolution under the assumption that the cataclastic flow involved in process (2) completely relieves the stresses accumulated under process (1), which would render the relaxation of their composite stresses in the subsequent cycle negligible. Thus, the stress evolution during an interseismic period is approximated here by application of the load and relaxation of the stresses generated by it during the cycle being considered. The precise character of the earthquake sequence(s), which may relieve the stresses at the end of the cycle, need not be specified. The adopted approximation satisfies the primary purpose of determining if the generated loading stresses are of the correct sense and magnitude to produce large NMSZ events.

The initiation and continuation of the earthquake cycle following the sudden weakening of the lower crust is modeled in terms of a coupled linear elastic-viscoelastic system (Fig. 3). This consists of purely elastic material in the top 16- $\mathrm{km}$ (upper crust) and below $40 \mathrm{~km}$ (upper mantle) and of viscoelastic material within the intervening lower crust. The viscosity structure of the lower crust has been chosen to satisfy the constraints that its viscosity decreases with depth because of the temperature increase with depth and 
Figure 3. The initiation of an earthquake cycle in the NMSZ following the sudden weakening of the lower crust is modeled in terms of a coupled linear elastic-viscoelastic system. Forward calculations of time-dependent displacement and shear stress resolved onto vertical planes are performed by distributing negatively buoyant rift pillow material over an area of radius $15 \mathrm{~km}$ at (a) $25-\mathrm{km}$ depth or (b) the base of the upper crust. In both cases the center of the applied load directly overlies the center of the rift pillow. Both initial static deformation and a snapshot of evolved deformation (after relaxation of the lower crust) are shown on a vertical plane bisecting the cylindrical area.
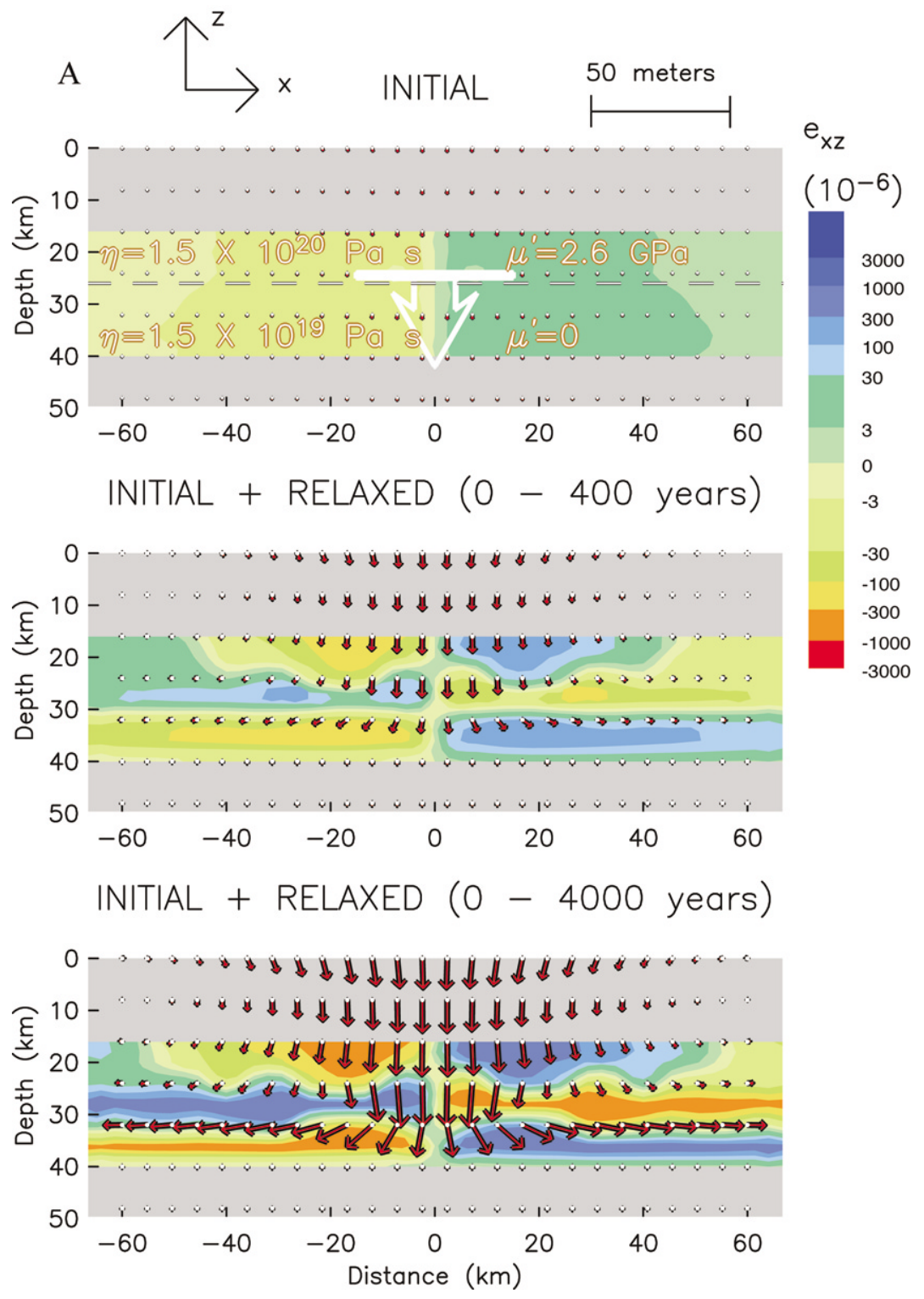

that it should be comparable with independent estimates of lower crustal viscosity. The lower crust has been divided into two layers of viscosities $\eta=1.5 \times 10^{20}$ and $\eta=1.5 \times$ $10^{19} \mathrm{~Pa}$ sec, respectively. The stronger layer is shallower and has viscosity consistent with that recently resolved by Kaufmann and Amelung (2000) in the western United States. The weaker layer possesses a Maxwell viscoelastic fluid rheology, and the stronger layer possesses a standard linear solid rheology (Cohen, 1982) with long-term strength $\mu^{\prime}=2.6$ $\mathrm{GPa}$. This assumed long-term strength is based on the existence of a positive free-air gravity anomaly of greater than about 20 mgal (McGinnis, 1970), suggesting that the dense rift pillow is at least partially supported by the upper and lower crust. The extreme age of the rift pillow requires that, if the proposed mechanism is operable, $\mu^{\prime}$ in part or all of the lower crust has never diminished below a certain mini- mum value, that is, if a Maxwell rheology had existed in the entire lower crust for any significant period of time since about 600 m.y. B.P., the rift pillow would already have sunk to the base of the crust and be isostatically supported by the denser mantle. We assume that it has been at least partially supported by the surrounding lower crust ever since its emplacement, and the recent weakening involved a sharp decrease in both $\eta$ and $\mu^{\prime}$ in the lower crust.

The degree to which support of the rift pillow had been partitioned between isostatic compensation in the mantle and elastic strain in the lower crust is unknown, but we assume for concreteness that support had been evenly divided between the two. Consequently we assume that $50 \%$ of the excess mass of the rift pillow with respect to the lower crust was converted into negative gravitational potential energy at the time of weakening. 


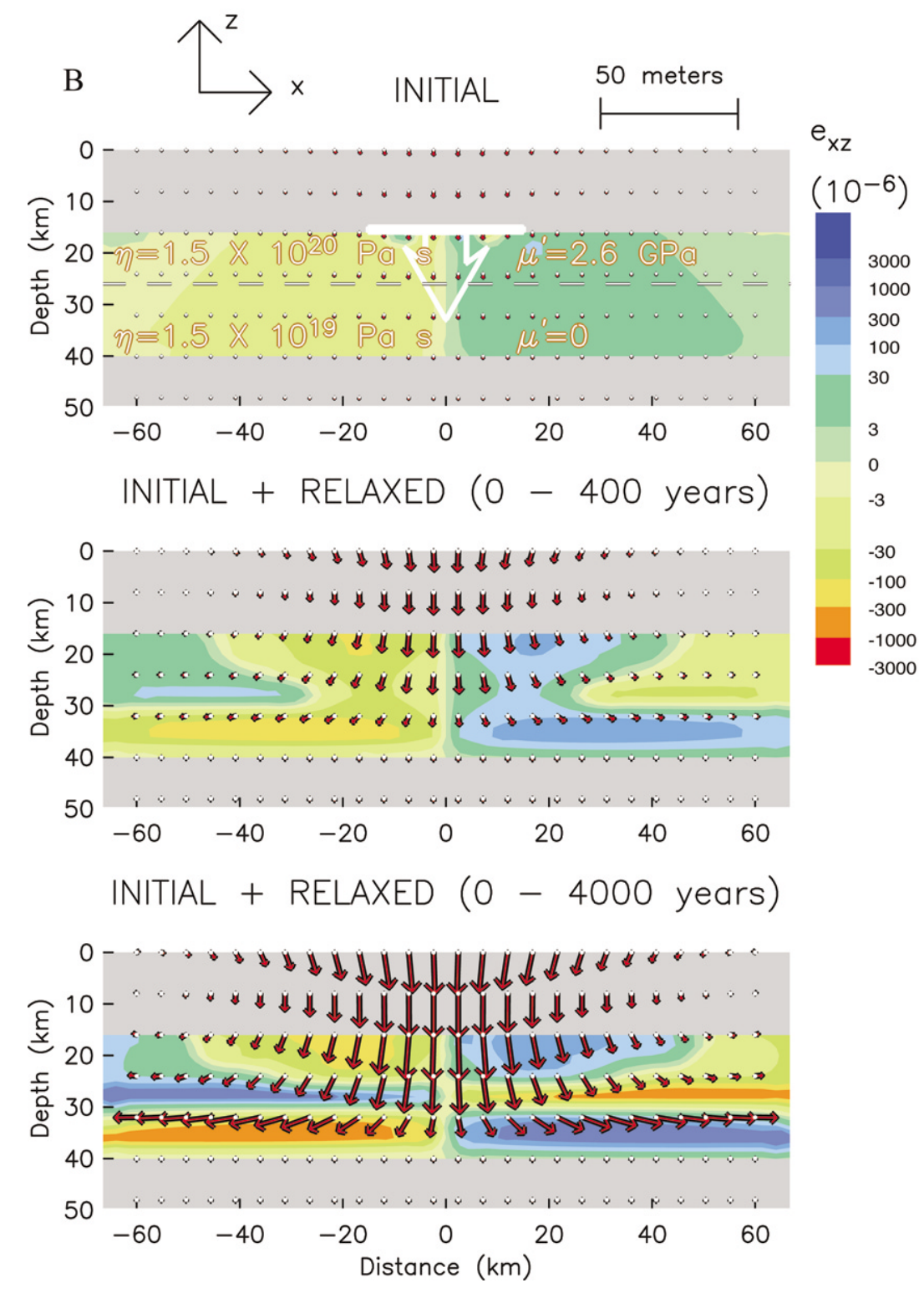

Figure 3. Continued.

\section{Evolution of Deformation}

Forward calculations of time-dependent deformation are performed by distributing a $1.5 \times 10^{4}-\mathrm{km}^{3}$ cylindrical volume of rift pillow material (density contrast $=150 \mathrm{~kg}$ / $\mathrm{m}^{3}$ ) over a circular area of radius $15 \mathrm{~km}$ at $25-\mathrm{km}$ depth directly overlying the center of the rift pillow (approximately at the Lake County uplift zone). The static and time-dependent components of deformation are calculated using the methods of Pollitz (1996, 1997, respectively) with appropriate modifications made to obtain and integrate Green's functions for distributed point forces. Figure 3A shows the displacement pattern on a profile bisecting the cylinder as well as shear strain resolved onto vertical planes, both for the initial time (immediately after application of the load) and at 400 or 4000 yr after subsequent relaxation of the lower crust. Significant rapid downwarping of the plate is accomplished within $400 \mathrm{yr}$. As we shall show, this leads to large stress concentration within the overlying upper crust. Depending on the actual viscoelastic stratification, our timedependent calculations show that the elapsed time necessary to produce an earthquake of slip approximately $5 \mathrm{~m}$ is on the order of 400-600 yr. Thus, a few hundred years elapsed time since application of the load is sufficient to produce failure on faults in the upper crust.

Figure 3B shows the corresponding displacement and strain pattern for the case in which the load is applied directly at the base of the upper crust. Comparison of Figure $3 \mathrm{~A}$ and $\mathrm{B}$ shows that while the induced flow pattern in the lower crust is dependent on the location of the load, the displacement field induced in the upper crust is similar. However, the magnitude of time-dependent deformation in the upper crust is decreased by about $30 \%$ by applying a 
load at greater depth because in that case the coupling of the force with the upper crust is eroded by lower crustal flow. Since the apex of the rift pillow is at about $25-\mathrm{km}$ depth (Stuart et al., 1997) we shall henceforth restrict attention to the case of loading at a depth of $25 \mathrm{~km}$.

The displacement patterns shown in Figure 3 are the product of the responses to initial static load and relaxation of the lower crust with time. The temporal evolution of horizontal velocity is of particular interest since Global Positioning System (GPS) measurements (Newman et al., 1999) suggest that very little $(-0.2 \pm 2.4 \mathrm{~mm} / \mathrm{yr})$ motion currently occurs in the right-lateral strike-slip sense about the NMSZ. Calculated horizontal and vertical velocities predicted on the sinking-pluton model are shown in Figure 4A,B. Assuming that the latest cycle began in 1812, it predicts that present-day surface deformation is characterized by horizontal motion directed radially toward the center of the step-over zone at a rate reaching $1.5 \mathrm{~mm} / \mathrm{yr}$ about $20 \mathrm{~km}$ from the center. Although available data do not have the spatial resolution or accuracy to test the details of this prediction, the GPS sites within $60 \mathrm{~km}$ of the step-over zone do exhibit a roughly radially symmetric pattern with a magnitude of $2-3 \mathrm{~mm} / \mathrm{yr}$ (Fig. 5A). To identify this pattern in the observed velocity field, we generated a set of synthetic horizontal velocity fields on the viscoelastic model, each evaluated $200 \mathrm{yr}$ after the initiation of the latest cycle, varying the location of the center of the rift pillow over a large grid. Each realization was then compared with the observed velocity field by evaluating the coherence

$$
\gamma=\frac{C_{12}}{\sqrt{C_{11} C_{22}}}
$$

where the correlation between velocity fields $\mathbf{v}_{i}$ and $\mathbf{v}_{j}$ at the considered GPS sites is defined as

$$
C_{i j}=\mathbf{v}_{i}^{T} \operatorname{Cov}^{-1} \mathbf{v}_{j} \quad(i, j=1,2)
$$

Here Cov is the covariance matrix for the observed horizontal velocity field, and subscripts 1 and 2 denote observed and synthetic velocity field, respectively. Letting $\mathbf{v}_{2}$ depend on the location $\hat{\mathbf{r}}$ of the center of the rift pillow, we calculate $\gamma$ as a function of $\hat{\mathbf{r}}$. The resulting distribution of coherence is shown in Figure 5B. The local maximum just southwest of the step-over zone is consistent with the position of the rift pillow (red contours). For consistency with the Coulomb failure results, we evaluate the synthetic velocity field at $\hat{\mathbf{r}}=36.40^{\circ} \mathrm{N}, 89.65^{\circ} \mathrm{W}$ and compare it with the observed velocity field in Figure 5A. The coherence between the two velocity fields is 0.33 . Clearly, the errors in the GPS data are much greater than the signal being sought, and the areas NW and SE of the step-over zone are not adequately covered. With more years of observations and improved coverage, a future comparison will be more meaningful.

The model also predicts present-day subsidence of about $6 \mathrm{~mm} / \mathrm{yr}$ within $10 \mathrm{~km}$ of the step-over zone, although

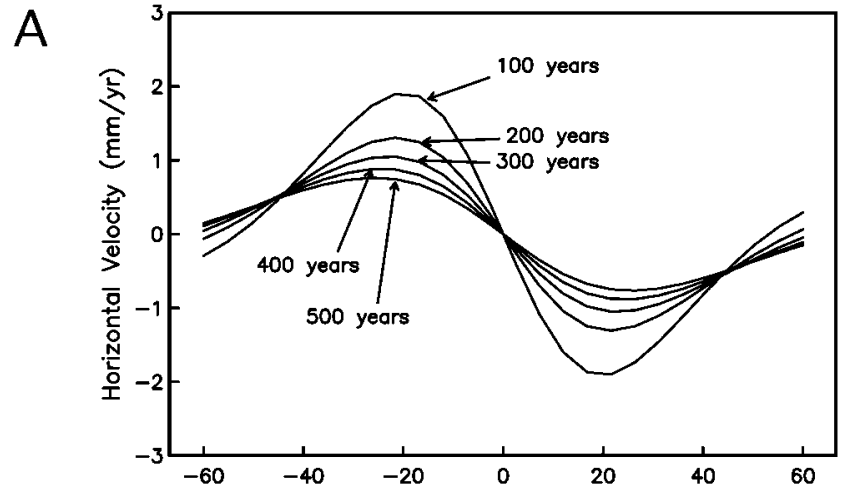

B

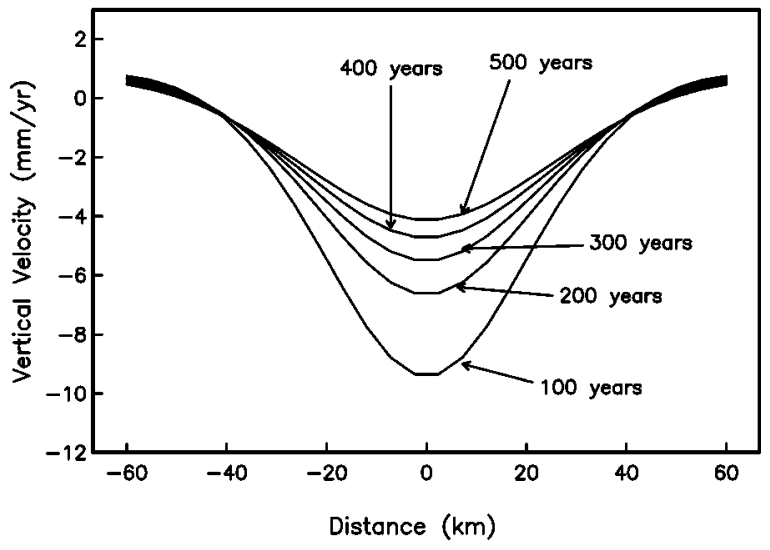

C

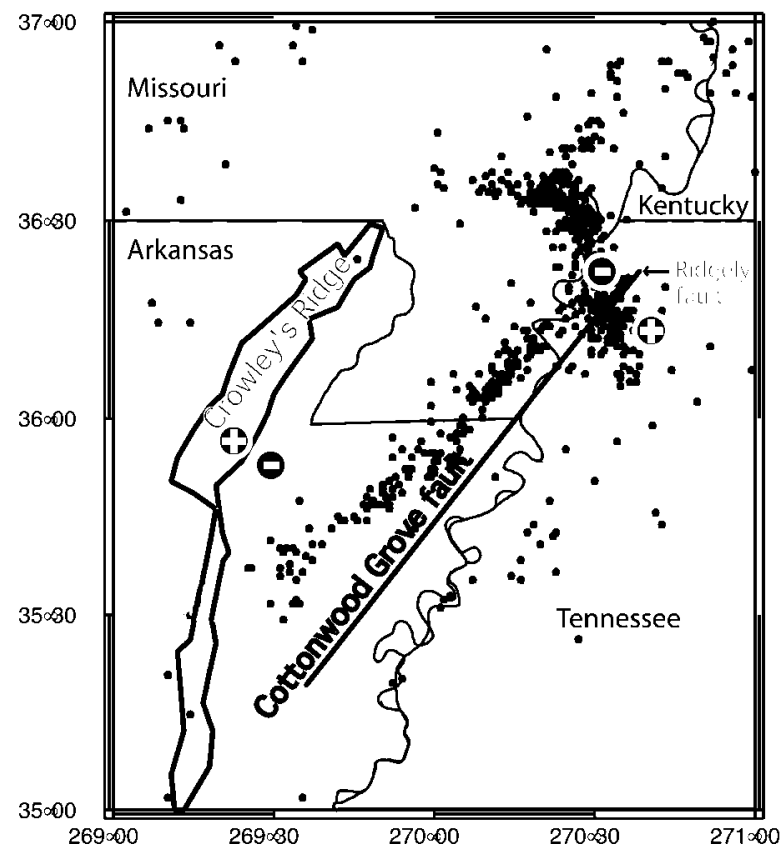

Figure 4. (A) Horizontal and (B) vertical velocity at Earth's surface as a function of distance from the upward projection of the center of the rift pillow and time since initiation of the load. Positive vertical velocity is reckoned up. (C) Locations of Crowley's Ridge and the Cottonwood and Ridgely faults. Plus $(+)$ and minus $(-)$ symbols indicate differential uplift across the indicated fault zones. 


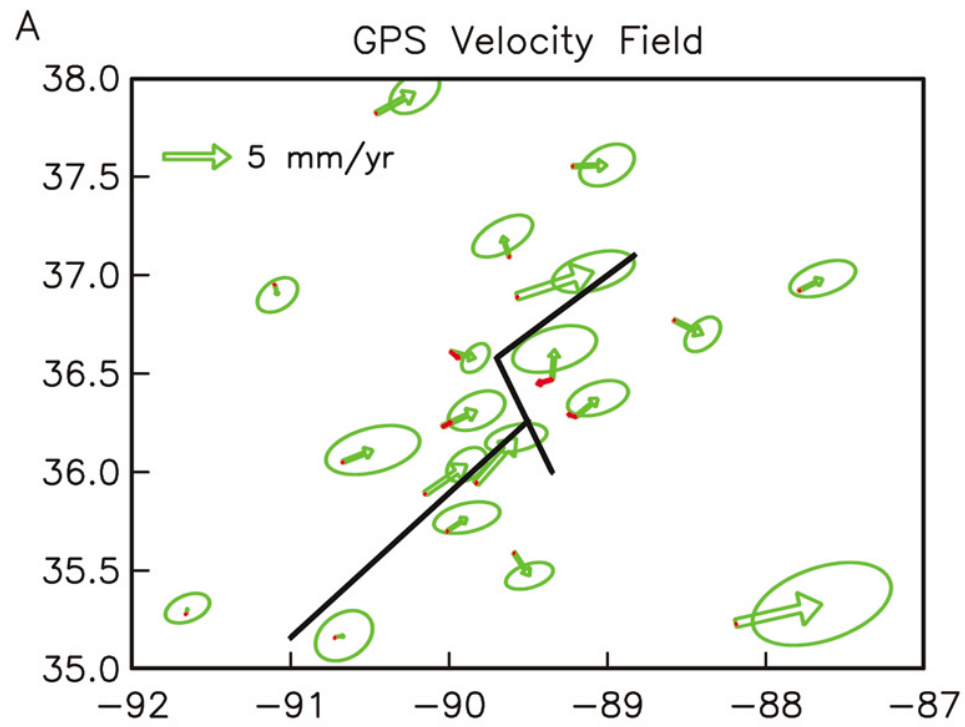

Figure 5. (A) Horizontal velocity field as constrained by GPS observations from 1993 to 1998 (Newman et al., 1999), with 95\% confidence ellipses, shown in green. The synthetic velocity field evaluated $200 \mathrm{yr}$ after the initiation of a cycle, assuming the center of the rift pillow to be $36.3^{\circ} \mathrm{N}, 89.6^{\circ} \mathrm{W}$, is shown in red. (B) Distribution of coherence $\gamma$ (equation (2)) between observed and synthetic velocity fields as a function of the center of the rift pillow. Depth contours $(\mathrm{km})$ to the top of the known imaged rift pillow are shown in red, as in Figure 1. The red " $\mathrm{x}$ " marks $36.40^{\circ} \mathrm{N}, 89.65^{\circ} \mathrm{W}$. Epicenters of $M$ 2.0-3.5 earthquakes from 1974 to 1998 are superimposed.

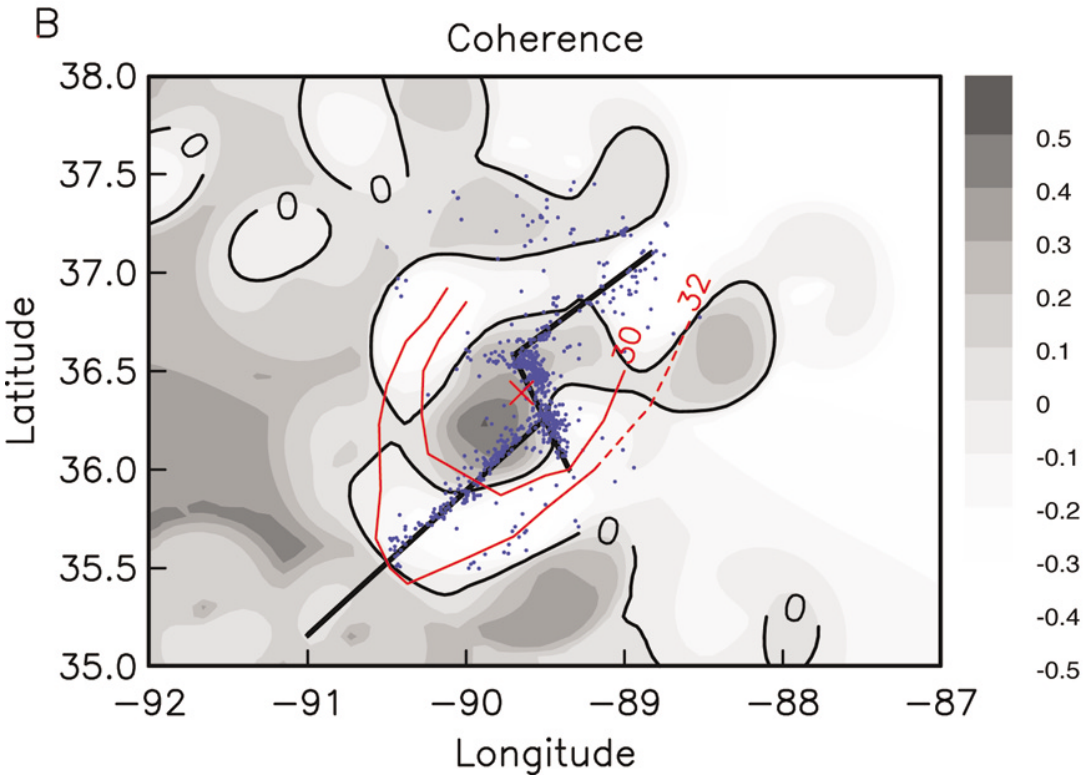

there are no geodetic observations available against which this could be tested. Subsidence of the step-over region as a whole is, however, strongly suggested by (1) eastward migration of the ancestral Ohio River from Crowley's Ridge to its present location (the Mississippi River south of the confluence between the two rivers), likely accompanied by faulting adjacent to Crowley's Ridge to produce differential uplift of it with respect to the NMSZ (Van Arsdale et al., 1995), and (2) Quaternary movements along the Cottonwood Grove and Ridgely faults, accommodating differential uplift of the area east of the NMSZ (Van Arsdale et al., 1998). This further suggests that plastic deformation associated with the sinking stresses may not be confined to just the Reelfoot fault and the strike-slip faults delineated by current seismicity.

Vertical displacement rates across the Reelfoot fault are about $4.4 \mathrm{~mm} / \mathrm{yr}$ over the past $2400 \mathrm{yr}$ and $6.2 \mathrm{~mm} / \mathrm{yr}$ during the two most recent earthquake cycles from the years 900 to 1812 (Van Arsdale, 2000), in good agreement with the average predicted subsidence rate over a 500-yr loading cycle (Fig. 4B). Both the horizontal and vertical velocity patterns are, however, very likely affected by viscoelastic relaxation following the earthquakes that terminated the previous cycle. The implicit assumption that such earthquakes exactly nullify the stresses built up during the loading period is only approximate, and it is likely that additional transient velocities modify the patterns depicted in Figures 4 and 5 (i.e., Rydelek and Pollitz, 1994). This would consist of a longwavelength right-lateral strike-slip velocity signal and an additional vertical signal. For example, if most of the thrust faulting which relieves the built-up stresses occurred in the deeper upper crust, then the additional vertical signal would 
tend to re-elevate the region with time (e.g., figure 6 of Pollitz, 1997) and negate the subsidence contributed by the loading process alone. In addition, plastic deformation associated with fault slip should be included in order to interpret local uplift rates. Indeed, the Lake County uplift is associated with about 15-m post-Eocene uplift (Van Arsdale et al., 1998), most of which must have accumulated over the past few thousand years if current displacement rates are applicable (Van Arsdale, 2000). This uplift would reflect the offsets accumulated during the loading process, coseismic offsets, and gradual postseismic recovery associated with past earthquakes.

\section{Stress Concentration}

The deformation patterns produced by lower crustal weakening may be related to earthquake occurrence by considering the associated change in Coulomb failure stress. For slip in a given sense on a prescribed fault, the Coulomb failure stress is defined as

$$
\Delta \sigma_{\mathrm{f}}=\Delta \tau+\mu_{\mathrm{eff}} \Delta \sigma_{\mathrm{n}}
$$

where $\Delta \tau$ is the change in shear stress (positive for a stress change promoting failure), $\Delta \sigma_{n}$ is the change in normal stress (positive tensile), and $\mu_{\text {eff }}$ is the effective coefficient of friction, taken to be 0.4 or 0.8 . The location of the vertical projection of the center of the rift pillow is chosen as $36.40^{\circ} \mathrm{N}$, $89.65^{\circ} \mathrm{W}$. The regional stress field (Fig. 1) is oriented so as to produce thrust faulting on NW-SE-striking faults. Thrustpromoting $\Delta \sigma_{f}$ on $\mathrm{N} 35^{\circ} \mathrm{W}$-trending, $30^{\circ}$-dipping hypothetical failure planes is evaluated at a depth of $5 \mathrm{~km}$ (Fig. 6A,C) or $10 \mathrm{~km}$ (Fig. 6B,D) and time $0^{+}$and $400 \mathrm{yr}$ after initiation of weakening in the viscoelastic system. The coefficient of friction is assigned values of 0.4 in Figure 6A,B and 0.8 in Figure 6C,D. Stresses evolve considerably with elapsed time into the cycle. The pattern of positive $\Delta \sigma_{f}$ is shaped like a funnel cloud, being narrow at greater depth $(10 \mathrm{~km})$ and broadening out at shallower depth $(5 \mathrm{~km})$. In particular, the well-developed thrust faulting within the step-over zone as well as its continuation to the southeast (outside of the stepover zone) is encompassed by the region of high $\Delta \sigma_{f}$. Similarly, strike-slip-promoting $\Delta \sigma_{f}$ on $\mathrm{N} 45^{\circ}$ E-trending, vertical hypothetical failure planes is evaluated at a depth of $5 \mathrm{~km}$ (Fig. 7A,C) or $10 \mathrm{~km}$ (Fig. 7B,D) and time $0^{+}$and $400 \mathrm{yr}$ after initiation of weakening in the viscoelastic system. The coefficient of friction is assigned values of 0.4 in Figure 7A,B and 0.8 in Figure 7C,D. Failure on both strike-slip fault arms (and the Bootheel lineament) is enhanced late in the cycle (i.e., at time $400 \mathrm{yr}$ ) but at a smaller level than the thrust-faulting enhancement. However, the two failure mechanisms are expected to be strongly coupled, and we postulate that significant strike-slip faulting is secondary in response to the strongly promoted thrust faulting at all depth levels around the step-over region.

In Figures 6 and 7, comparing 6C,D with 6A,B and
7C,D with 7A,B, the coefficient of friction is seen to exert only a moderate influence on the pattern of Coulomb failure stress, the essential stressing pattern remaining unchanged. The greatest sensitivity to the coefficient of friction is for enhancement of strike-slip faulting at shallow depth, where $\Delta \sigma_{f}$ is increased considerably by taking $\mu^{\prime}=0.8$ (Fig. 7C) versus $\mu^{\prime}=0.4$ (Fig. 7A).

\section{Sinking of a Dense Body through a Viscous Fluid}

The cycle of stress buildup and release in the NMSZ is interpreted as a product of the inexorable sinking of an anomalously dense body situated in the ductile lower crust. It has been assumed that the flow field in the shallower crust excited by the specified distributed downward force at 25$\mathrm{km}$ depth (Fig. 3A) resembles that expected for sinking of a finite body of the same dimension as the force distribution $(\sim 30 \mathrm{~km})$. In the case of sinking of a finite body, the resistance to sinking is a combination of pressure and viscous drag of the surrounding viscous material, and a balance of forces between the excess gravitational mass of the body and the viscous drag can constrain its sinking velocity and hence the overall flow field.

We consider the velocity field associated with a negatively buoyant viscous sphere sinking through another viscous fluid (Hadamard-Rybczynski equation; Clift et al., 1978). The steady-state sinking velocity is

$$
v=\frac{1}{3} \frac{\Delta \rho g r^{2}}{\eta}\left[\frac{\eta+\eta_{\mathrm{sph}}}{\eta+\frac{3}{2} \eta_{\mathrm{sph}}}\right]
$$

The parameters in equation (4) taken for the mafic body are $\Delta \rho=$ density contrast $\sim 150 \mathrm{~kg} / \mathrm{m}^{3} ; r=$ radius of mafic body $\sim 10-15 \mathrm{~km} ; g=$ gravitational acceleration $\sim 10 \mathrm{~m} /$ $\sec ^{2} ; \eta, \eta_{s p h}=$ viscosity of surroundings and spherical inclusion, respectively. We assign a viscosity of $\eta=10^{20} \mathrm{~Pa}$ sec to the lower crust, roughly equivalent to the two-layer stratification used in the deformation calculations. We employ equation (4) under the additional assumption that $\eta_{s p h} \gg \eta$, in which case the flow generated by the sinking sphere reduces to Stokes' flow.

With the aforementioned estimates we obtain a steadystate sinking velocity of $v=1.4-3.2 \mathrm{~cm} / \mathrm{yr}$. The flow field obtained by the viscoelastic model averaged over the first $400 \mathrm{yr}$ of a cycle is shown in Figure 8A and compared with the Stokes flow field associated with a sphere of radius 12.5$\mathrm{km}$ sinking at $2 \mathrm{~cm} / \mathrm{yr}$ (Fig. 8B). The two flow fields are very similar at depths shallower than $\sim 25 \mathrm{~km}$, demonstrating that the flow field associated with a sinking finite body has similar consequences for upper crustal deformation as that excited by the distributed forces on the viscoelastic model.

Since only one major thrust structure (the Reelfoot fault) is thought to accommodate vertical stress release, the amounts of sinking of the dense body and consequent slip 
on the thrust fault should be similar. Figure 8B shows that the flow field in the vicinity of the sphere is geometrically attenuated by about $50 \%$ at a distance comparable to upper crustal depth, that is, $v \sim 1 \mathrm{~cm} / \mathrm{yr}$ at such depth. This would imply a recurrence interval for thrust faulting events of $5 \mathrm{~m} /$ $v \sim 500 \mathrm{yr}$. This estimate presumably applies to strike-slip faulting events as well since thrust and strike-slip faulting are likely highly coupled in the NMSZ. This is the same as the geologically estimated recurrence interval of 400-600 $\mathrm{yr}$, showing that the analog model of a $25-\mathrm{km}$-diameter sphere sinking beneath the NMSZ at a rate of $2 \mathrm{~cm} / \mathrm{yr}$ is a reasonable representation of the average seismic cycle in the NMSZ, especially considering that the rift pillow has a highly nonspherical, lense-like shape (Stuart et al., 1997) and that the flow is resisted additionally by flexural forces of the elastic plate.

\section{Discussion and Conclusions}

Our model postulates an active role for the dense rift pillow underlying the NMSZ. Prior to the Holocene, the rift pillow was partially compensated by depression of the crustmantle boundary, but it was also partially supported by the lower crust. Following a recent weakening of the lower crust and upper mantle, which we believe is related to the dynamics of postglacial flow, support for the rift pillow was lost and it began to sink. The questions of how long the rift pillow has been gravitationally unstable, how support for the rift pillow was partitioned between the crust and mantle prior to the Holocene, and precisely how weakening of these regions was accomplished are important but remain unresolved. Even if the rift pillow had reached isostatic equilibrium sometime after its initial emplacement $\sim 600$ m.y. B.P., a further destabilizing mechanism may be that the ancient rift pillow was enlarged through melting of the underlying mantle during the Cretaceous thermal event, residual portions of the mantle became depleted in Fe relative to $\mathrm{Mg}$, and thus the negative buoyancy of the rift pillow increased at that time. As far as the consequences of sinking are concerned, however, the proposed stress concentration model is not contingent upon specific mechanisms of destabilization and weakening but only requires that lower crustal weakening occurred simultaneously with the Holocene acceleration in NMSZ deformation rates.

Whatever the mechanism of weakening, an issue recently raised by Grollimund and Zoback (2001) concerns the precise relation of past deglaciations to accelerated deformation in the NMSZ. The main constraints on total deformation within the NMSZ are $15 \mathrm{~m}$ of post-Eocene uplift within the Reelfoot fault zone (Van Arsdale and TenBrink, 2000), the occurrence of three slip events along the Reelfoot fault over the past $2400 \mathrm{yr}$ (Kelson et al., 1996), and the occurrence of three large strike-slip events of comparable size on the SW arm since 800 A.D. (and possibly two or three additional strike-slip events since 4035 B.C.) (Tuttle and Schweig, 1995). Present deformation rates in the Reelfoot fault, if extrapolated directly into the past, could not have persisted for more than about $2400 \mathrm{yr}$, that is, well within the post-Laurentide deglacial epoch. However, a series of several ice sheet advances and retreats of comparable with the most recent Laurentide glaciation have been documented in the Central Plains during the Pleistocene (Richmond and Fullerton, 1986), and one might expect corresponding cycles of NMSZ deformation associated with each glaciation. One way of addressing this is to postulate that present rates may only be applicable to the period spanned by documented earthquake occurrence. If deglaciationinduced crustal weakening and consequent deformation has a significant lag time, then deformation may accelerate only several thousand years after deglaciation. This affords the possibility of distributing total post-Eocene accumulated deformation among the several Pleistocene and Holocene postglacial epochs, and it would be consistent with the known chronology of seismic activity in the NMSZ.

Sinking of the mafic body led to large tensile vertical stress concentration in the upper crust directly above it. Simple calculations of the response of the elastic upper crust to the estimated loads applied at its base show that, in the presence of the regional ENE-WSW compressive stress, Coulomb failure stress steps of $10^{1}-10^{2}$ bars are generated to promote thrust faulting on NW-SE-trending faults at all depths and right-lateral strike-slip faulting on deeper (8-16 $\mathrm{km}) \mathrm{NE}-\mathrm{SW}$-trending vertical faults. The promotion of thrust and reverse faulting is especially strong within the upper crustal domain directly above the mafic body, and it may potentially lead to substantial secondary strike-slip faulting on NE-SW-trending vertical faults marginal to the zone of most intense thrust faulting. Following a large set of earthquakes in the NMSZ, reloading and subsequent renewal of these stress concentrations would be accomplished by further sinking of the mafic body, beginning the cycle anew.

Although shallow reverse faulting has produced localized uplift (Lake county uplift), our model predicts flexural downwarping associated with the downward-pulling mafic body. This appears consistent with the Quaternary history of rerouting of the Mississippi river, characterized by an eastward migration of the ancestral Ohio River and diversion of the ancestral Mississippi River to its present confluence with the Ohio River north of the NMSZ (Van Arsdale et al., 1995). This is supported by a substantial post-Eocene differential uplift east of the step-over zone on the Cottonwood Grove and Ridgely faults (Van Arsdale et al., 1998). Further tests of the proposed stress concentration model could be achieved with longer and more distributed GPS observations, a better understanding of the Quaternary movements on the faults bounding Crowley's Ridge, independent evidence for lower crustal weakening in the fault zone, and high-resolution seismic imaging of the lower crust and upper mantle beneath the NMSZ. 

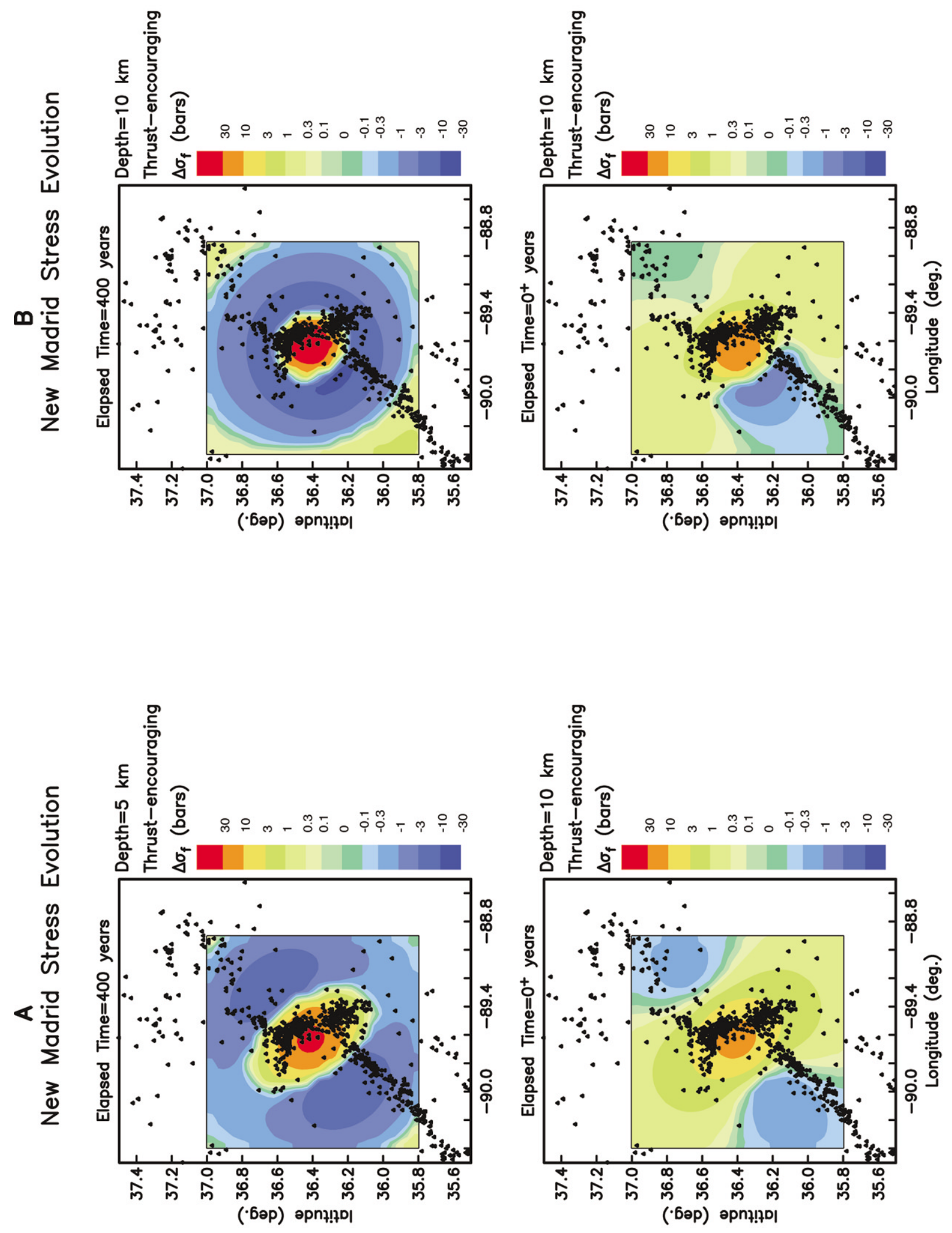

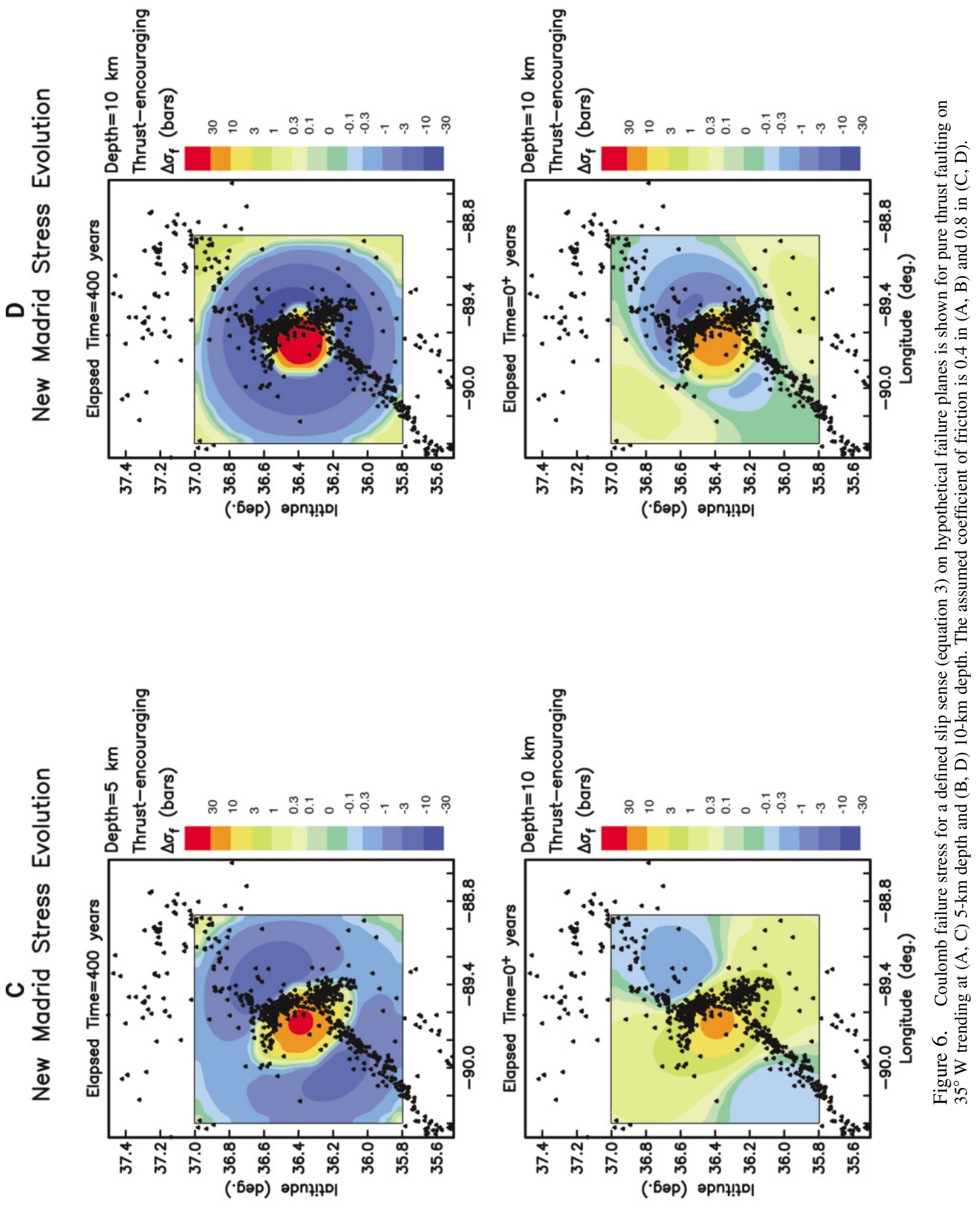


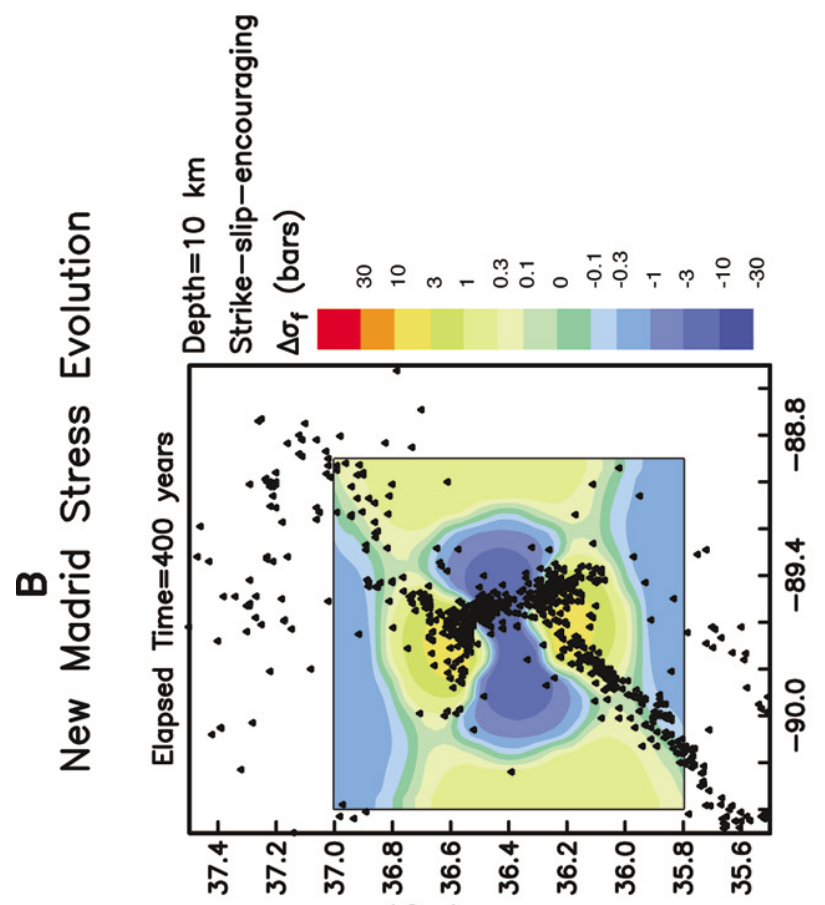

(·Бр) әрп7!?ㅣ
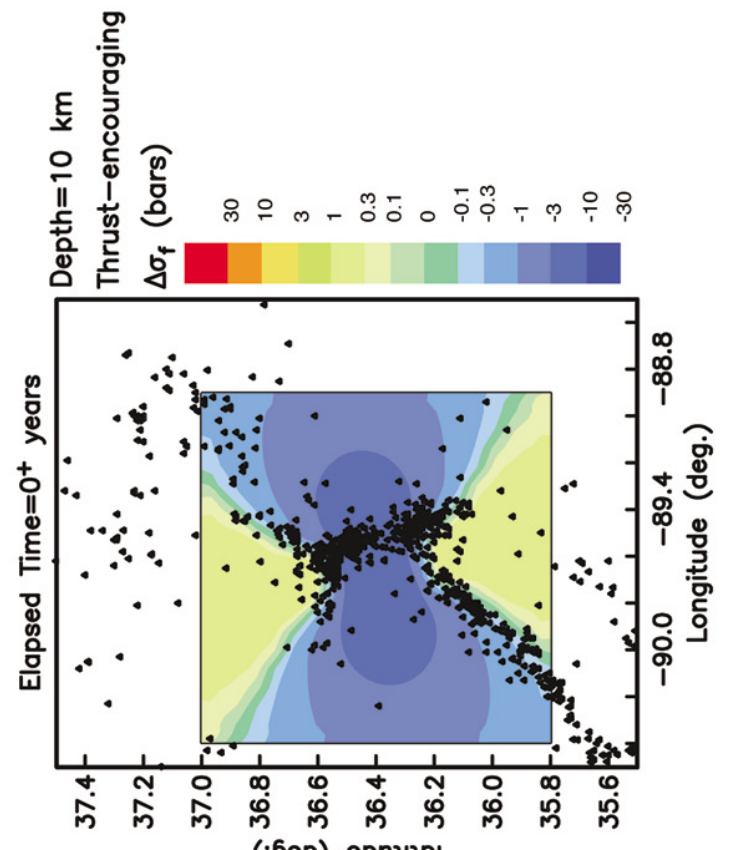

('6әр) әрn?!?미
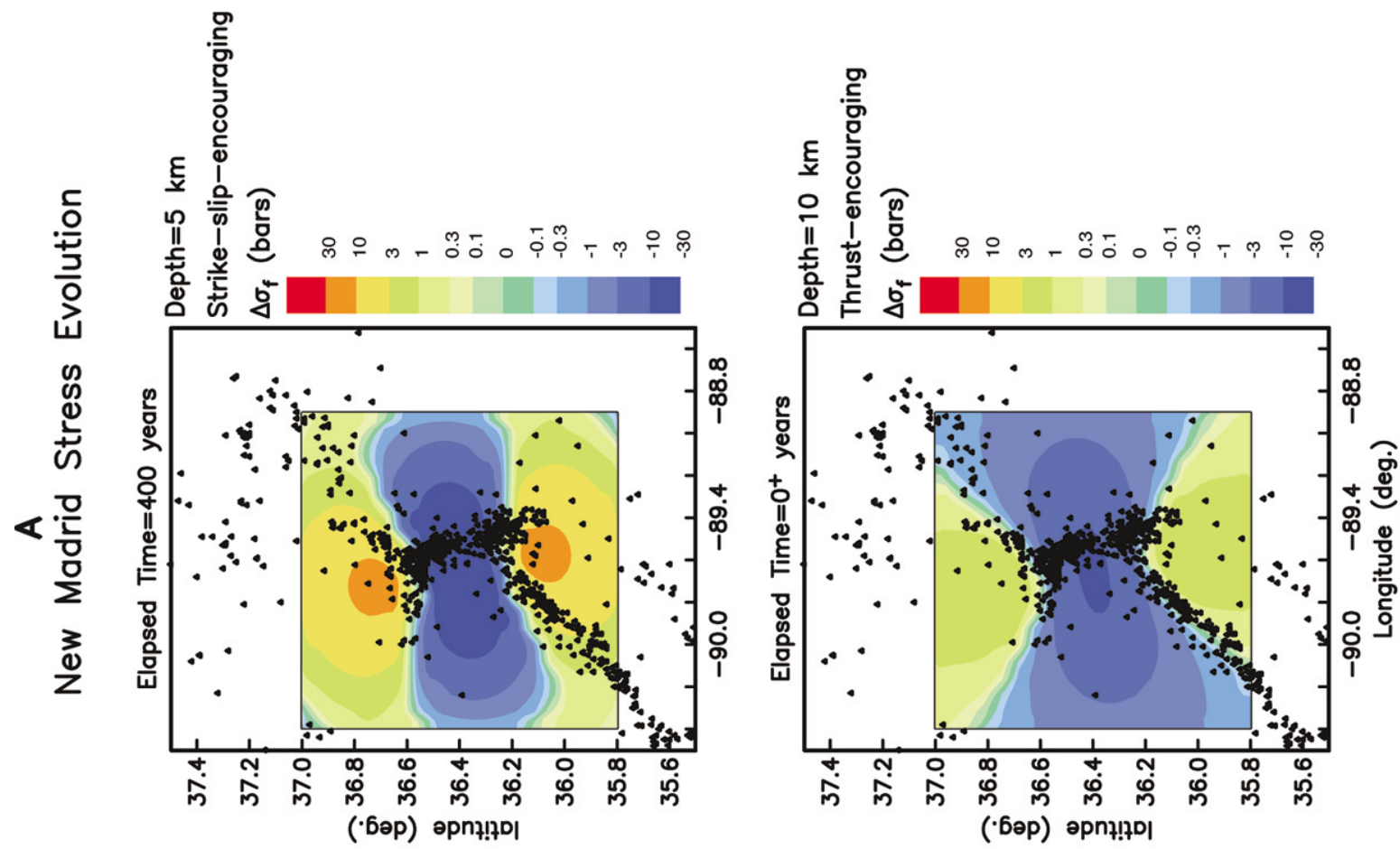

1894 

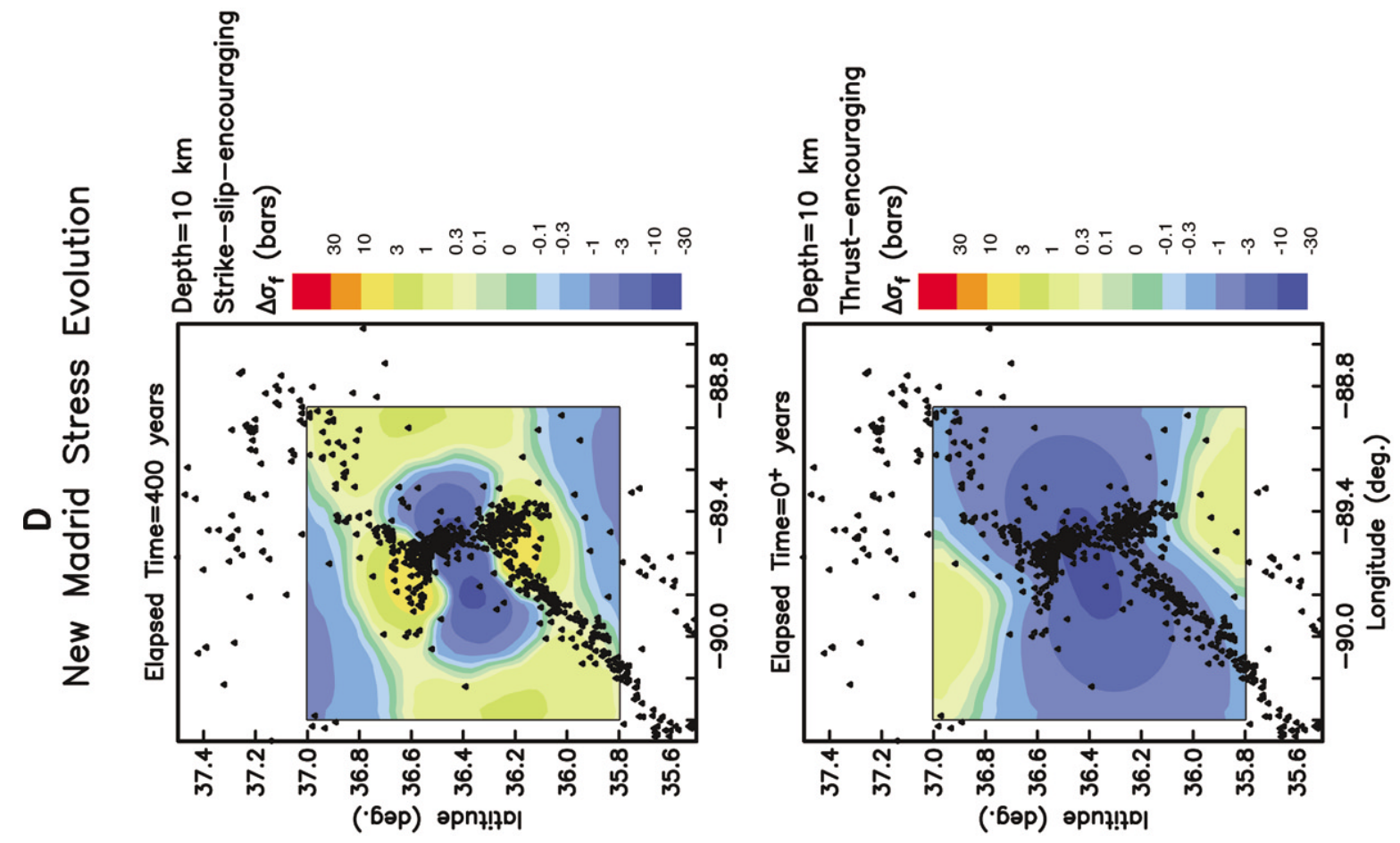

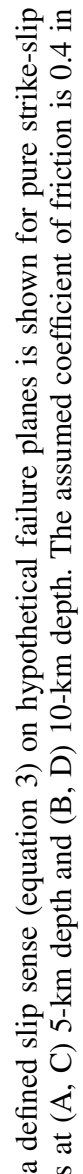
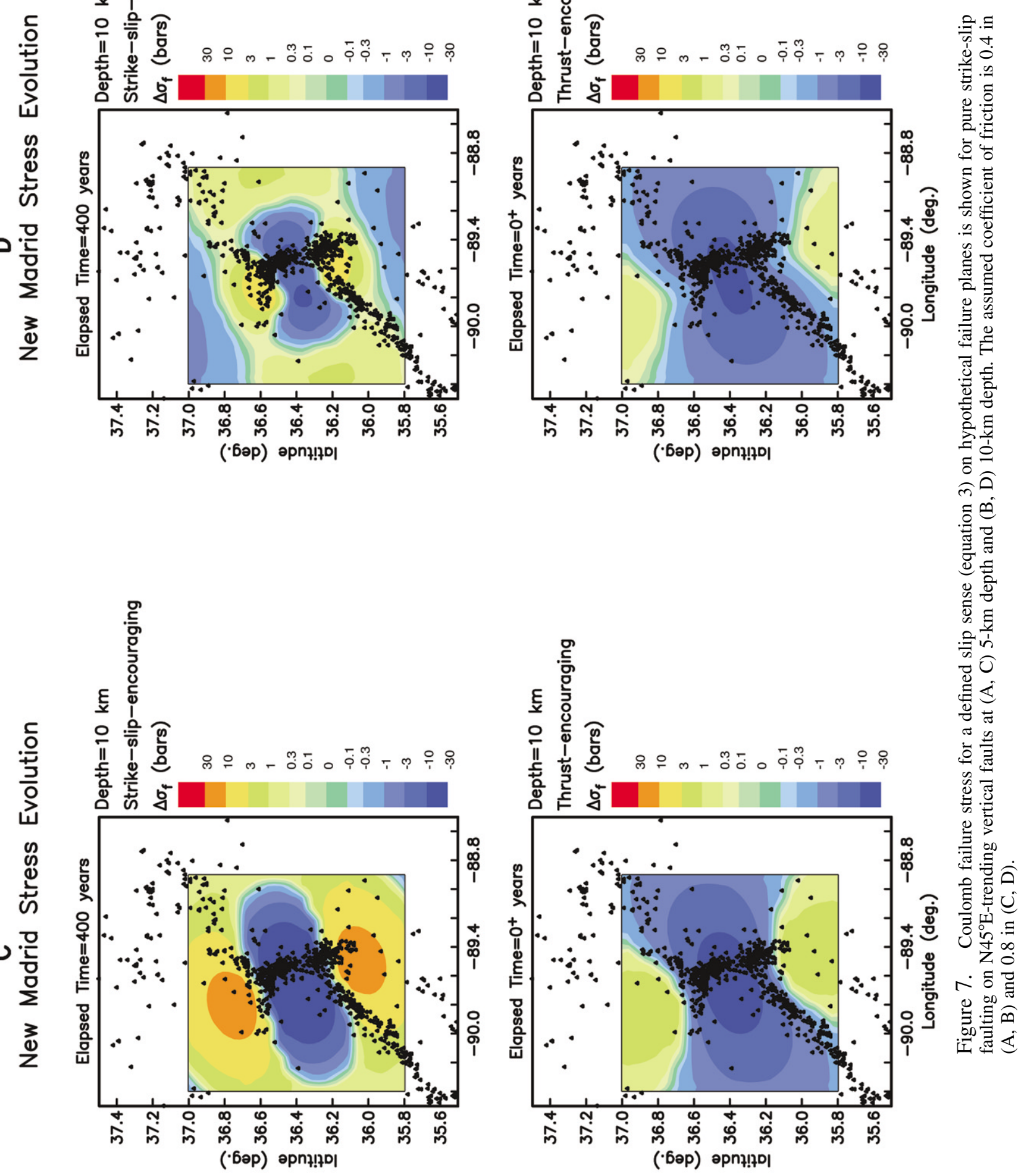

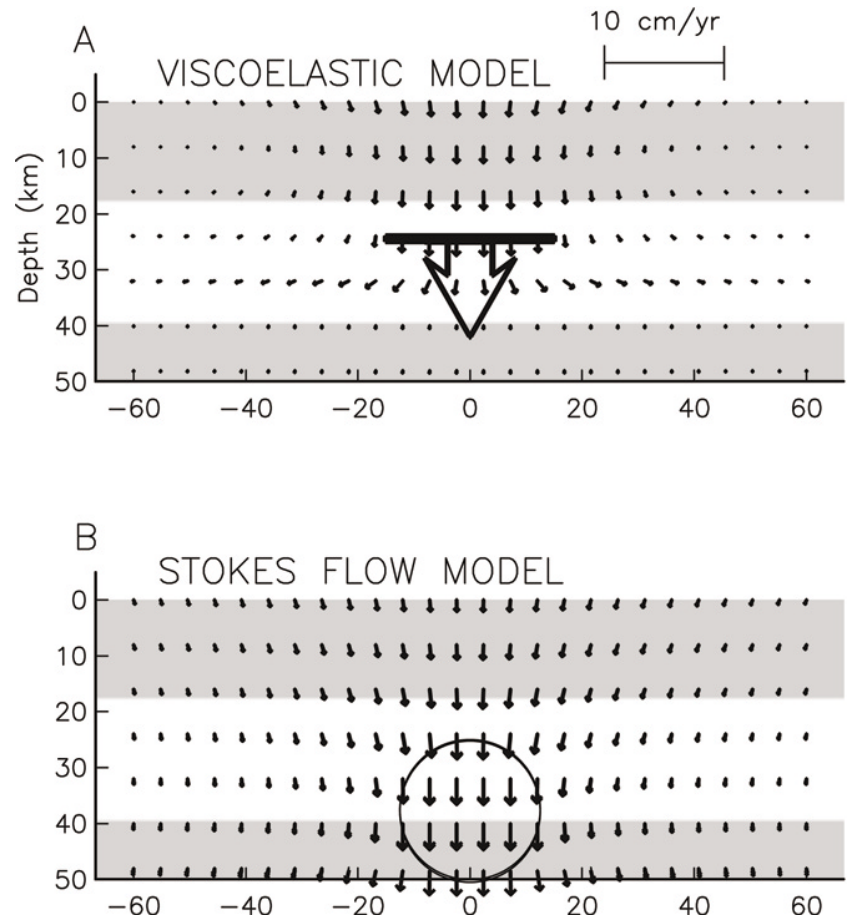

Figure 8. Flow fields associated with (A) distributed force on the viscoelastic model, averaged over the first 400-yr of a seismic cycle, and (B) Stokes' flow associated with a $25-\mathrm{km}$-diameter sphere sinking through a viscous fluid at a rate of $2 \mathrm{~cm} / \mathrm{yr}$. The flow fields in Figures 3A and 8A are identical.

\section{Acknowledgments}

This work was partially supported by the IGPP Program of Lawrence Livermore National Laboratory while F.F.P. was a postdoctoral researcher at UC Davis. We thank Seth Stein for making available the GPS velocity field, Janice Fong for assistance with graphics, and Walter Mooney, William Stuart, Wayne Thatcher, Jiakang Xie, and Mary Lou Zoback for valuable discussions. Constructive comments from two anonymous reviewers and Martin Chapman are gratefully acknowledged.

\section{References}

Al-Shukri, H. J., and B. J. Mitchell (1987). Three-dimensional velocity variations and their relation to the structure and tectonic evolution of the New Madrid seismic zone, J. Geophys. Res. 92, 6377-6390.

Baker, J., G. Chazot, M. Menzies, and M. Thirlwall (1998). Metasomatization of the shallow mantle beneath Yemen by the Afar plumeimplications for mantle plumes, flood volcanism, and intraplate volcanism, Geology 26, 431-434.

Braile, L. W., W. J. Hinze, G. R. Geller, E. G. Lidiak, and J. L. Sexton (1986). Tectonic development of the New Madrid rift complex, Mississippi Embayment, North America, Tectonophysics 131, 1-21.

Campbell, D. L. (1978). Investigations of the stress-concentration mechanism for intraplate earthquakes, Geophys. Res. Lett. 5, 477-479.

Chiu, J. M., A. C. Johnston, and Y. T. Yang (1992). Imaging the active faults of the central New Madrid seismic zone using PANDA array data, Seism. Res. Lett. 63, 375-393.

Clift, R., J. R. Grace, and M. E. Weber (1978). Bubbles, Drops, and Particles, Academic, New York.

Cohen, S. C. (1982). A multilayer model of time dependent deformation following an earthquake on a strike slip fault, J. Geophys. Res. 87, 5409-5421.

Cox, R. T., and R. B. Van Arsdale (1997). Hotspot origin of the Mississippi embayment and its possible impact on contemporary seismicity, Eng. Geol. 46, 5-12.

Crough, S. T., W. J. Morgan, and R. B. Hargraves (1980). Kimberlites: their relation to mantle hotspots, Earth Planet. Sci. Lett. 50, 260-274.

Dyke, A. S., and V. K. Prest (1987). Late Wisconsinan and Holocene history of the Laurentide ice sheet, Geograph. Phys. Quat. 61, 237-263.

Ervin, C. P., and L. D. McGinnis (1975). Reelfoot rift-reactivated precursor to the Mississippi Embayment, Geol. Soc. Am. Bull. 86, 1287 1295.

Ginzburg, A., W. D. Mooney, A. W. Walter, W. J. Lutter, and J. H. Healy (1983). Deep structure of northern Mississippi embayment, $A A P G$ Bull. 67, 2031-2046.

Gomberg, J., and M. Ellis (1994). Topography and tectonics of the central New Madrid seismic zone: results of numerical experiments using a three-dimensional boundary element program, J. Geophys. Res. 99, 20,299-20,310.

Grana, J. P., and R. M. Richardson (1996). Tectonic stress within the New Madrid seismic zone, J. Geophys. Res. 101, 5445-5458.

Grollimund, B., and M. D. Zoback (2001). Did deglaciation trigger intraplate seismicity in the New Madrid seismic zone? Geology 29, 175178.

Herrmann, R. B. (1979). Surface wave focal mechanism studies for eastern North American earthquakes with tectonic implications, J. Geophys. Res. 84, 3543-3552.

Herrmann, R. B., and J.-A. Canas (1978). Focal mechanism studies in the New Madrid seismic zone, Bull. Seism. Soc. Am. 68, 1095-1102.

Hildenbrand, T. G. (1985). Rift structure of the northern Mississippi embayment from analysis of gravity and magnetic data, J. Geophys. Res. 90, 12,607-12,622.

Hildenbrand, T. G., and J. D. Hendricks (1995). Geophysical setting of the Reelfoot Rift and relations between rift structures and the New Madrid seismic zone, in Investigations of the New Madrid Seismic Zone, K. M. Shedlock and A. C. Johnston (Editors), U.S. Geol. Surv. Prof. Pap. 1538-E, E1-E30.

Hitchings, R. S., M. S. Paterson, and J. Bitmead (1989). Effects of iron and magnetite additions in olivine-pyroxene rheology, Phys. Earth Planet. Interiors 55, 277-291.

Hough, S. E., J. G. Armbruster, L. Seeber, and J. F. Hough (2000). On the modified Mercalli intensities and magnitudes of the 1811-1812 New Madrid earthquakes, J. Geophys. Res. 105, 23,839-23,864.

Johnston, A. C. (1996). Seismic moment assessment of earthquakes in stable continental regions. III. New Madrid 1811-1812, Charleston 1886 and Lisbon 1755, Geophys. J. Int. 126, 314-344.

Johnston, P., P. Wu, and K. Lambeck (1998). Dependence of horizontal stress magnitude on load dimension in glacial rebound models, Geophys. J. Int. 132, 41-60.

Jull, M., and D. McKenzie (1996). The effect of deglaciation on mantle melting beneath Iceland, J. Geophys. Res. 101, 21,815-21,828.

Karato, S.-I., and P. Wu (1993). Rheology of the upper mantle: a synthesis, Science 260, 771-778.

Kaufmann, G., and F. Amelung (2000). Reservoir-induced deformation and continental rheology in vicinity of Lake Mead, Nevada, J. Geophys. Res. 105, 16,341-16,358.

Kelson, K. I., G. D. Simpson, R. B. Arsdale, C. C. Haraden, and W. R. Lettis (1996). Multiple late Holocene earthquakes along the Reelfoot fault, central New Madrid seismic zone, J. Geophys. Res. 101, 61516170.

Kenner, S., and P. Segall (2000). A mechanical model for intraplate earthquakes; application to the New Madrid seismic zone, Science 289, 2329-2332.

Liu, L. (1993). Continental seismotectonics: stress, strain, and strength, Ph.D. Thesis, Stanford University, Stanford.

Liu, L., and M. D. Zoback (1997). Lithospheric strength and intraplate seismicity in the New Madrid seismic zone, Tectonics 16, 585-595. 
Long, L. T. (1976). Speculations concerning southeastern earthquakes, mafic intrusions, gravity anomalies, and stress amplification, Earthquake Notes 47, 29-35.

McGinnis, L. D. (1970). Tectonics and the gravity field in the continental interior, J. Geophys. Res. 75, 317-331.

McKeown, F. A., and S. F. Diehl (1994). Evidence of contemporary and ancient excess fluid pressure in the New Madrid seismic zone of the Reelfoot Rift, central United States, in Investigations of the New Madrid Seismic Zone, K. M. Shedlock and A. C. Johnston (Editors), U.S. Geol. Surv. Profess. Pap. 1538-N. N1-N24.

Mitchell, B. J., C. C. Cheng, and W. Stauder (1977). A three-dimensional velocity model of the lithosphere beneath the New Madrid seismic zone, Bull. Seism. Soc. Am. 67, 1061-1074.

Mooney, W. D., M. C. Andrews, A. Ginzburg, D. A. Peters, and R. M. Hamilton (1983). Crustal structure of the northern Mississippi embayment and a comparison with other continental rift zones, Tectonophysics 94, 327-348.

Newman, A., S. Stein, J. Weber, J. Engeln, A. Mao, and T. Dixon (1999). Slow deformation and lower seismic hazard at the New Madrid seismic zone, Science 284, 619-621.

O’Connell, D. R., C. G. Bufe, and M. D. Zoback (1982). Microearthquakes and faulting in the area of New Madrid, Missouri-Reelfoot Lake, Tennessee, in Investigations of the New Madrid, Missouri, Earthquakes Region, F. A. McKeown and L. C. Pakiser (Editors), U.S. Geol. Surv. Prof. Pap. 1236, 31-38.

Peltier, W. R., and X. Jiang (1996). Mantle viscosity from the simultaneous inversion of multiple data sets pertaining to postglacial rebound, Geophys. Res. Lett. 23, 503-506.

Pollitz, F. F. (1996). Coseismic deformation from earthquake faulting on a layered spherical Earth, Geophys. J. Int. 125, 1-14.

Pollitz, F. F. (1997). Gravitational-viscoelastic postseismic relaxation on a layered spherical Earth, J. Geophys. Res. 102, 17,921-17,941.

Richmond, G. M., and D. S. Fullerton (1986). Summation of Quaternary glaciations in the United States of America, in Quaternary Glaciations in the Northern Hemisphere, V. Sibrava, D. Q. Bowen, and G. M. Richmond (Editors), Permagon, Oxford.

Rydelek, P., and F. F. Pollitz (1994). Fossil strain from the 1811-1812 New Madrid earthquakes, Geophys. Res. Lett. 21, 2303-2306.

Schott, B., D. A. Yuen, and H. Schmeling (1999). Viscous heating in heterogeneous media as applied to the thermal interaction between the crust and mantle, Geophys. Res. Lett. 26, 513-516.

Stauder, W. (1982). Present-day seismicity and identification of active faults in the New Madrid seismic zone, in Investigations of the New Madrid, Missouri, Earthquakes Region, F. A. McKeown and L. C. Pakiser (Editors), U.S. Geol. Surv. Prof. Pap. 1236, 31-38.

Stuart, W. D., T. G. Hildenbrand, and R. W. Simpson (1997). Stressing of the New Madrid seismic zone by an lower crust detachment fault, $J$. Geophys. Res. 102, 27,623-27,633.
Swanberg, C. A., B. J. Mitchell, R. L. Lohse, and D. D. Blackwell (1982) Heat flow in the upper Mississippi embayment, in Investigations of the New Madrid, Missouri, Earthquakes Region, F. A. McKeown and L. C. Pakiser (Editors), U.S. Geol. Surv. Prof. Pap. 1236, 185-189.

Thomas, W. A. (1991). The Appalachian-Ouachita rifted margin of southeastern North America, Geol. Soc. Am. Bull. 103, 415-431.

Tuttle, M. P., and E. S. Schweig (1995). Archaeological and pedalogical evidence for large prehistoric earthquakes in the New Madrid seismic zone, central United States, Geology 23, 253-256.

Van Arsdale, R. B. (2000). Displacement history and slip rate on the Reelfoot fault of the New Madrid seismic zone, Eng. Geol. 55, 219-226.

Van Arsdale, R. B., and R. K. TenBrink (2000). Late Cretaceous and Cenozoic geology of the New Madrid seismic zone, Bull. Seism. Soc. Am. 90, 345-356.

Van Arsdale, R. B., J. Purser, W. Stephensen, and J. Odum (1998). Faulting along the southern margin of Reelfoot Lake, Tennessee, Seism. Res. Lett. 88, 131-139.

Van Arsdale, R. B., R. A. Williams, E. S. Schweig, E. S. Shedlock, J. K. Odum, and K. W. King (1995). The origin of Crowley's Ridge, northeastern Arkansas, erosional remnant or tectonic uplift? Bull. Seism. Soc. Am. 85, 963-985.

Wesnousky, S. G., and L. M. Leffler (1992). The repeat time of the 1811 and 1812 New Madrid earthquakes; a geological perspective, Bull. Seism. Soc. Am. 82, 1756-1785.

White, R., and D. P. McKenzie (1989). Magmatism at rift zones: the generation of volcanic continental margins and flood basalts, J. Geophys. Res. 94, 7685-7729.

U.S. Geological Survey

345 Middlefield Road, MS 977

Menlo Park, California 94025

fpollitz@usgs.gov

(F.F.P.)

Department of Geology

1 Shields Ave.

University of California, Davis

Davis, California 95616

(L.K.)

Department of Geology and Geophysics

McCone Hall

University of California, Berkeley

Berkeley, California 94720

(R.B.)

Manuscript received 15 November 2000. 